UDC 159.922.76:376

\title{
AUTISTIC CHILDREN VERBAL AND NON-VERBAL COMMUNICATION DEVELOPMENT
}

\author{
AUTHOR'S DATA: \\ Nelly Hunanyan, Researcher \\ Chair of Speech and Rehabilitative Therapy, Khachatur Abovyan Armenian State Pedagogical University \\ Lecturer \\ Contacts: nellyhunanyan@ rambler.ru
}

\begin{abstract}
The article presents the results of the study, which relates to the efficacy of speech therapy means and methods for the development of speech and non-verbal communication processes for children with autism.

A number of researchers' observations show that the range of contact between children with autism is very limited. Mostly these children feel calm and they are relatively manageable only among their extremely close people. The difficulty of selective and original communication contributes to the more isolation of children with autism. The communication difficulties described in the context of not performing early diagnostics work start to be strengthened and deeply rooted in the mental processes of these children. The inability to communicate and the active rejection of any communication contributes to relapsing behaviors whenever there is an attempt to draw any attention and the requirement for a directive ends with a fight.

Based on the multi-year pedagogical activity in this field, the author presents experimental studies with autistic children. Taking into account the individual features of each child during the two-year training, we have created different play situations to try to make an interest and expand the range of contacts. Initially, we tried to create about 5-10 similar situations during one speech therapy session, and later, when appropriate skill is well-formed, we try to strengthen it in other situations or in the presence of other strangers.
\end{abstract}

Keywords: Early autism (EA), verbal communication, non-verbal communication, socialization, alternative communication tools, speech therapy sessions. 


\section{INTRODUCTION}

Over the past few years, the concept of "autism" has been widely distributed among the public. Such curiosity shown by the people as well as the importance of the topic of this article is not accidental as the number of children with such diagnosis increases year by year in the world (Petrova, 2010; Greenspan \& Wieder, 2013; Svajyan \& Manukyan, 2015). The children are born with undiscovered and unique behaviors that lack the abiity to communicate with surrounding people (Hunanyan, 2013).

It is known that the speech process of children with early autism (EA) has unique and pathological development (Kovalyov, 1985; Nurieva, 2003; Mastyukova \& Moskovkina, 2004; Sukiasyan \& Margaryan, 2006; Happe, 2006; Kafyan, 2010). The difficulties associated with the verbal process, as well as the lack of desire to communicate, occur at an early age and persist throughout the life of these children (Mesh \& Wolf, 2003). It is a fact that there are children with EA who can speak and have certain language skills, but the reproduction of words out of context does not lead to real development and children stop using these words bcause they do not understand the purpose of their application. Therefore, the main reason of the communication difficulties of children with EA is an insufficient reciprocity and, in fact, the inability to understand the meaning of information transfer from one person to another as a communication tool (Gilbert \& Piters, 2005).

The aim of this research is to promote the socialization process of children with EA by identifying potential ways of forming and developing verbal and non-verbal communication in these children.

\section{METHODS}

For this study we conducted experimental training with participation of 28 children with EA aged 4-7, 14 of them were included in experimental and 14 in the control groups. Individual work was carried out with children with EA in the control group, based on the basic speech therapy methodologies for playing and learning. In the experimental group, the work for development of the communication process for children with EA was carried out through the use of a speech therapy system developed by us in playing and learning processes. In this system, in order to develop verbal and non-verbal communication capabilities for these children, during individual, and later during group training, we have purposefully implemented the following (Figure 1): 
1. Expanding the frame of contact between children with EA;

2. Formation and development of the ability to use verbal communication tools;

3. Formation and development of the ability to use non-verbal or body-based (somatic) lingual means, in particular gestures;

Formation and development of communication skills with the help of alternative communication tools, like pictures and writing.

Figure 1. Ways to develop verbal and non-verbal communication tools for children with early autism.

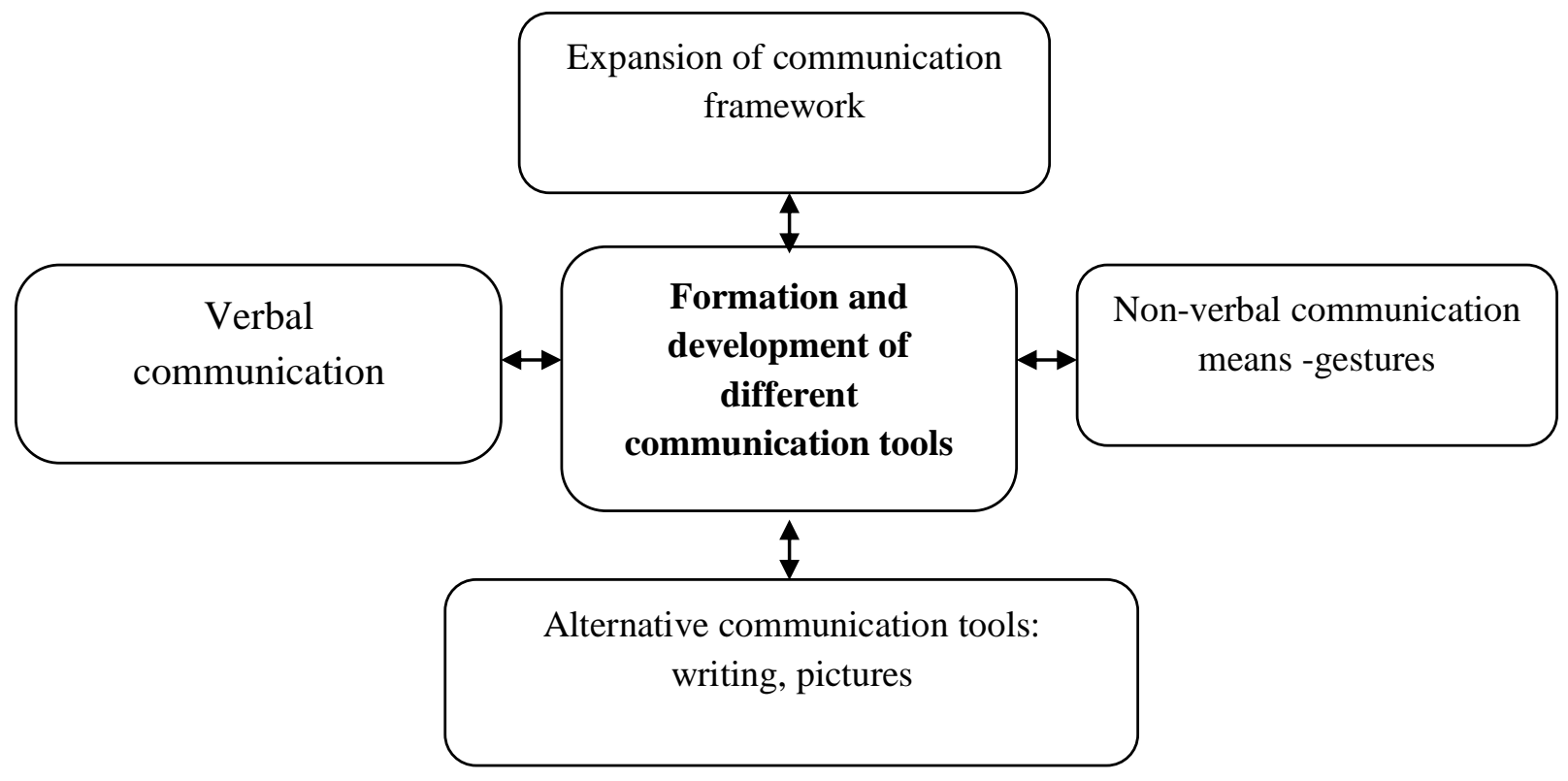

Taking into consideration the possible ways of communication of children with EA (speech, gesture, picture, etc.), the speech therapy intervention carried out by us for the formation and development of communication capabilities has pursued the following goals:

- Formation and development the ability to apply "Yes" response or appropriate gesture in children with EA through the specialist's question "Do you want?";

- Formation and development the ability to apply "No" response or appropriate gesture in children with EA through the specialist's question "Do you want?"; 
- Formation and development of the ability to apply the "Demonstration" gesture by children with EA;

- Formation and development of the ability to comment on actions performed by children with EA (through speech or related images).

In order to accomplish the aforementioned work, we have chosen preferably incentives (food, items, etc.) for each child to encourage them and include in speech therapy intervention for the formation and development of communication capabilities. During the implementation of the works by this regard we also relied upon the communicative skills-enhancing behavioral method (Gilbert \& Piters, 2005).

The reliability of the positive results we have recorded has been tested in the both, context of the reality (when a child with EA playing by train, for example, is commanded: "Give the train" or "Take the train", etc.), as well as beyond the context of reality (in this case a child with EA is given an instruction that does not asociated with the child's action at that moment, for example, "Give the cube", "Come Here", etc.) (Nikolskaya, Baenskaya \& Libling, 1997; Lovaas, 2003).

During the two-year experimental training, taking into account the individual characteristics of each child, we have created different playing and learning situations for the purpose of creating interest and expanding the range of their contacts.

\section{RESULTS AND DISCUSSION}

For the formation and development the ability to apply "Yes" response or appropriate gesture in children with EA through the question "Do you want?" we have shown the incentive interesting for the child with EA and have asked him "Do you want?". Then, immediately, as the hint, we have given the word "Yes" or with the motion of the head have shown the appropriate positive gesture. As a result of two-year experimental training, we have made the following progress: before experimental training in both control and experimental groups only $21.42 \%$ (3 children) of children with EA were able to answer "Yes" verbally to the question "Do you want?", and two years later, this indicator increased to $28.57 \%$ ( 4 children) in the control group and to $42.85 \%$ (6 children) in the experimental group (Table 1). It should also be noted that before experimental training none of the groups of children with EA gave the answer "Yes" as the appropriate positive gesture with the head to the question "Do you want?" (Table 2). After the experimental training, $28.57 \%$ ( 4 children) of speechless children with EA in the experimental 
group used the gesture "Yes", but no positive progress was recorded in the control group (Table 2).

Table 1. Comparative indicators of the development of verbal communication means of the tested children

\begin{tabular}{|c|c|c|c|c|c|c|c|c|c|}
\hline \multirow{4}{*}{ 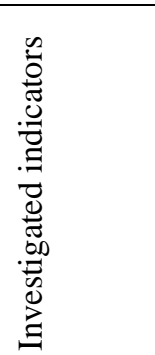 } & \multicolumn{5}{|c|}{ Experimental group $(n=14)$} & \multicolumn{4}{|c|}{ Control group $(n=14)$} \\
\hline & \multicolumn{5}{|c|}{ Evaluation units (points) } & \multicolumn{4}{|c|}{ Evaluation units (points) } \\
\hline & \multicolumn{3}{|c|}{ Before experiment } & \multicolumn{2}{|c|}{ After experiment } & \multicolumn{2}{|c|}{ Before experiment } & \multicolumn{2}{|c|}{ After experiment } \\
\hline & $\frac{\mathrm{n}}{\%}$ & $\begin{array}{c}\text { Existence } \\
\text { of verbal } \\
\text { response }\end{array}$ & $\begin{array}{l}\text { Absence } \\
\text { of Verbal } \\
\text { Response }\end{array}$ & $\begin{array}{l}\text { Existence } \\
\text { of verbal } \\
\text { response }\end{array}$ & $\begin{array}{l}\text { Absence } \\
\text { of Verbal } \\
\text { Response }\end{array}$ & $\begin{array}{l}\text { Existence } \\
\text { of verbal } \\
\text { response }\end{array}$ & $\begin{array}{l}\text { Absence } \\
\text { of Verbal } \\
\text { Response }\end{array}$ & $\begin{array}{l}\text { Existence } \\
\text { of verbal } \\
\text { response }\end{array}$ & $\begin{array}{l}\text { Absence } \\
\text { of Verbal } \\
\text { Response }\end{array}$ \\
\hline $\begin{array}{l}\text { Availability } \\
\text { of the } \\
\text { answer }\end{array}$ & $\mathrm{n}$ & 3 & 11 & 6 & 8 & 3 & 11 & 4 & 10 \\
\hline $\begin{array}{l}\text { "Yes" to the } \\
\text { question } \\
\text { "Do you } \\
\text { want?" }\end{array}$ & $\%$ & 21,42 & 78,57 & 42,85 & 57,14 & 21,42 & 78,57 & 28,57 & 71,42 \\
\hline $\begin{array}{l}\text { Availability } \\
\text { of the } \\
\text { answer }\end{array}$ & $\mathrm{n}$ & 1 & 13 & 5 & 9 & 2 & 12 & 2 & 12 \\
\hline $\begin{array}{l}\text { "No" to the } \\
\text { question } \\
\text { "Do you } \\
\text { want?" }\end{array}$ & $\%$ & 7,14 & 92,85 & 35,71 & 64,28 & 14,28 & 85,71 & 14,28 & 85,71 \\
\hline $\begin{array}{l}\text { Ability to } \\
\text { comment } \\
\text { on the } \\
\text { action }\end{array}$ & $\mathrm{n}$ & 1 & 13 & 5 & 9 & 1 & 13 & 2 & 12 \\
\hline performed & $\%$ & 7,14 & 92,85 & 35,71 & 64,28 & 7,14 & 92,85 & 14,28 & 85,71 \\
\hline
\end{tabular}

The principle of the work for the formation and development the ability to use "No" response (or appropriate gesture) by children with EA through the question "Do you want?" was the same as the previous one. In order to organize the work properly, we have chosen a meal or an item that the child really did not want based on, of course, their individual characteristics. It should be noted that the described works have been carried out several times during one logopedic training. As a result of the experimental training, we recorded the following progress: if only $14.28 \%$ ( 2 children) of the children with EA in the control group used this ability, two years later 
this index was not changed (Table 1). It should be noted that, after experimental training, the control group did not use the appropriate gesture of "No", as well (Table 2). The picture of the positive changes recorded was different in the experimental group where, before the experimental training, only $7,14 \%$ of children ( 1 child) were able to use the answer "No", and after experimental training it was 35,71\% (5 children) (Table 1). After the question "Do you want?", the appropriate gesture of "No" was used by $21.42 \%$ (3 children) of children with EA in the experimental group (Table 2).

Table 2. Comparative indicators of the development of non-verbal communication means

of the tested children

\begin{tabular}{|c|c|c|c|c|c|c|c|c|c|}
\hline \multirow{4}{*}{ 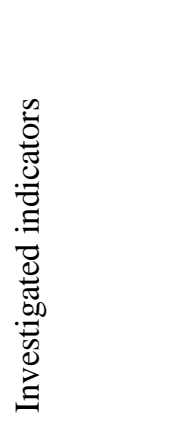 } & \multicolumn{5}{|c|}{ Experimental group $(n=14)$} & \multicolumn{4}{|c|}{ Control group $(n=14)$} \\
\hline & \multicolumn{5}{|c|}{ Evaluation units (points) } & \multicolumn{4}{|c|}{ Evaluation units (points) } \\
\hline & \multicolumn{3}{|c|}{ Before experiment } & \multicolumn{2}{|c|}{ After experiment } & \multicolumn{2}{|c|}{ Before experiment } & \multicolumn{2}{|c|}{ After experiment } \\
\hline & $\%$ & $\begin{array}{l}\text { Appropriate } \\
\text { gesture } \\
\text { application }\end{array}$ & $\begin{array}{c}\text { Absence of } \\
\text { appropriate } \\
\text { gesture } \\
\text { application }\end{array}$ & $\begin{array}{l}\text { Appropriate } \\
\text { gesture } \\
\text { application }\end{array}$ & $\begin{array}{c}\text { Absence of } \\
\text { appropriate } \\
\text { gesture } \\
\text { application }\end{array}$ & $\begin{array}{l}\text { Appropriate } \\
\text { gesture } \\
\text { application }\end{array}$ & $\begin{array}{c}\text { Absence of } \\
\text { appropriate } \\
\text { gesture } \\
\text { application }\end{array}$ & $\begin{array}{l}\text { Appropriate } \\
\text { gesture } \\
\text { application }\end{array}$ & $\begin{array}{l}\text { Absence of } \\
\text { appropriate } \\
\text { gesture } \\
\text { application }\end{array}$ \\
\hline $\begin{array}{l}\text { Application of } \\
\text { the }\end{array}$ & $\mathrm{n}$ & - & 14 & 4 & 10 & - & 14 & - & 14 \\
\hline $\begin{array}{l}\text { corresponding } \\
\text { gesture of the } \\
\text { answer "Yes" } \\
\text { to the question } \\
\text { "Do you } \\
\text { want?" }\end{array}$ & $\%$ & - & 100 & 28,57 & 71,42 & - & 100 & - & 100 \\
\hline $\begin{array}{l}\text { Application of } \\
\text { the }\end{array}$ & $\mathrm{n}$ & - & 14 & 3 & 11 & - & 14 & - & 14 \\
\hline $\begin{array}{l}\text { corresponding } \\
\text { gesture of the } \\
\text { answer "No" } \\
\text { to the question } \\
\text { "Do you } \\
\text { want?" }\end{array}$ & $\%$ & - & 100 & 21,42 & 78,57 & - & 100 & - & 100 \\
\hline $\begin{array}{l}\text { Ability to } \\
\text { comment on }\end{array}$ & $\mathrm{n}$ & - & 14 & 3 & 11 & - & 14 & - & 14 \\
\hline $\begin{array}{l}\text { performed } \\
\text { actions } \\
\text { through } \\
\text { pictures }\end{array}$ & $\%$ & - & 100 & 21,42 & 78,57 & - & 100 & - & 100 \\
\hline
\end{tabular}


The ability to use a "Demonstration" gesture is considered as one of the most important goals of our work, as children should express their wishes and reach the contact in both speech therapy work and everyday life. At first, as an example, we have shown how to use the "Demonstration" gesture, and then we have encouraged the child to use it independently as much as possible. Study has shown that before the experimental training only $21.42 \%$ ( 3 children) of the children with EA in control and experimental groups were able to apply the "Demonstration" gesture, but after the experimental training the $28.57 \%$ ( 4 children) and $71.42 \%$ (10 children) was recorded in the control and experimental groups, appropriately (Table 2).

For the purpose of forming and developing the capacity of children with EA to comment on their own actions, we have taught them to describe the action performed or to show the picture depicting the action. Initially, we have spoken the verbal material or have shown the picture of the right action instead of the child, and then gradually reduced our direct participation. Children were encouraged when with the little guidance at the initial stage, and later fully independently, performed the work described (Nurieva, 2003). The ability of examined children with EA to make comments on their own actions explored through the question "What do you do?". As one can see from the Table 1, before experimental training only 7,14\% (1 child) of children with EA included in control group was able to describe the limited number of their actions, but two years later, this index was increased up to $14.28 \%$ ( 2 children). In the experimental group, before experimental training $7.14 \%$ ( 1 child) of children were able to describe verbally the actions they performed and $35.71 \%$ ( 5 children) after the experimental training (Table 1). It should be noted that only $21.42 \%$ ( 3 children) of the non-verbal children in the experimental group were able to show the picture of the corresponding action on the question "What do you do?" (Table 2). Children with EA in the control group did not even show the picture depicting the appropriate action after the question "What do you do?" (Table 2).

\section{CONCLUSION}

The results of our experimental training allow us to identify the ways of formation and development of verbal and non-verbal communication skills of the children with EA, and substantiate experimentally the effectiveness of suggested speech therapy intervention program. 
Further research is needed to understand the wider possibilities of promotion the socialization process of children with EA by identifying potential communication ways of these children.

\section{REFERENCE LIST}

1. Gilbert, K., Piters, T. (2005) Autizm, medicinskoe i pedagogicheskoe vozdeystvie (Autism, Medical and Pedagogical intervention), Moskva, Vlados, s. 144.

2. Greenspan, S. \& Wieder, S., (2013) Engaging Autism: Using the Floortime Approach to Help Children Relate, Communicate, and Think (A Merloyd Lawrence Book): Moscow Publ. Terevinf.

3. Happe, F. (2006) Autism: An Introduction to Psychological Theory: Routledge

4. Hunanyan, N. V. (2013) Vagh mankakan autizmi meknabanutyan jamanakakic motecumneri verlucutyuny (An analysis of contemporary approaches to interpreting early childhood autism), Hayastani gitutyunneri azgayin akademia, Erebuni bzhshkakan kentron N 4 (56), Yerevan, ej 10-16

5. Kafyan, E. M. (2010) Autizmov erekhaneri zargacumy nerarakan usucman ev dastiarakutyan hamakargum (Development of children with autism in the system of inclusive education and upbringing), Profesoradasakhosakan andznakazmi, aspirantneri, haycordneri ev gitashkhatoghneri 54-rd gitajoghovi nyuteri joghovacu 1 PRAK: Yerevan, Mankavarzh, ej 125-127

6. Kovalyov, V. V. (1985) Semiotika I diagnostika psikhicheskikh zabolevaniy u detey I podrostkov (Semiotics and diagnostics of psychiatric patients in childhood and adolescence), Moskva, Medicina, s. 288

7. Lovaas, I. O. (2003) Teaching Individuals with Developmental Delays. Basic Intervention Techniques: An International Publisher PRO-ED.

8. Mastyukova, E. M., Moskovkina, A. G. (2004) Semeynoe vospitanie detey s otkloneniyami $\mathrm{v}$ razvitii (Family education for children with developmental disabilities), Moskva, Vlados, s. 408 c.

9. Mesh, E., Wolf, D. (2003) Detskaya patopsikhologiya. Narusheniye psikhiki rebenka (Pediatric pathology. Disordered Psychic Rebound) Trtya mejdunarodnoe izdanie, SanktPeterburg Praym - EVROZNAK, Moskva, Olma-Press, s. 512 
10. Nikolskaya, O. S., Baenskaya, E. R., Libling, M. M. (1997) Autichniy rebenok. Puti pomoschi (Autistic child. Ways of help.), Moskva, Terevinf, s. 341

11. Nurieva, L. G. (2003) Razvitie rechi u autichnikh detey, Moskvam Terevinf 2006, s. 160

12. Petrova, N. (2010) Puteshestviya s Aliaoy, ili razbitoe zazerkalye (Traveling with Alice, or the Broken Looking Glass), Moskva-Sankt-Peterburg Dilya, s.144

13. Sukiasyan, S. H., Margaryan, S. P. (2006) Hogebujutyun. Mas 1 (Psychiatry. Part 1) Yerevan Asoghik, ej 193

14. Svajyan, A. H., Manukyan, A. T. (2015) Autizm unecogh erekhanerin hanrakrtutyan mej nerarman himnaharcer (Issues for inclusion of children with autism in general education), Hatuk krtutyan himnakhndiner gitametodakan hands N 3, Yerevan, ej 119-124 